\title{
Research on the Innovation of Education Management under Concept of the Rule of Law in College
}

\author{
Hongbo $\mathrm{Xiu}^{1, \text { a }}$ \\ ${ }^{1}$ College of Automobile \& Civil Engineering, Beihua University, Jilin 132013, China. \\ ahongbo_xiu@126.com
}

Keywords: rule of law, student management concept, duties and responsibilities.

\begin{abstract}
Under strategy of the rule of law, the unity of rights and duties, of duties and responsibilities inevitably mean the come university students' free activities and the taking of responsibilities. the university student's education should turn from people's tool value to the value of free and full development. In this paper, the effective methods of combining theory and practice is used for guiding university students' taking of responsibilities lies in completing the emphasizing citizens' theoretical education and of responsibility education, into social practice.
\end{abstract}

\section{Introduction}

Concept is the forerunner and basis for action. Student Management concept from the global education system restricts the content management theory students, the process of law, modalities and institutional mechanisms to fundamentally affect student education management practices and activities to expand the actual results. Therefore, the students of educational management innovation, simply depending on student education management philosophy is correct or not, whether or not advanced. Therefore, deals with university education management innovation, we must first correct understanding of student education management concept.

From the analysis of the etymology, "concept" is exotic, translated "idea and elides", the creation by the Greek Pythagoreans. According to research, the ancient Greek philosopher Socrates lead its initial interpretation. He will explain the concept of people's minds thinking, philosophy is about the universality of the concept of identity, in any case reflects its identity and unity. Thus, from a philosophical sense, through the interpretation of the concept of Socrates, deconstruction previous philosophy, the philosophy introduced new direction, "so that the philosopher thinking from the perspective of the natural phenomenon itself turned to the people to seek human reason the highest expression ability."

Socrates, Plato on the basis of the concept of interpretation, based on the contents of its concept as a core philosophy, and as the basis for building its philosophy Philosophical system. Based on the concept of species Plato's theory, the idea is both logical discussion, also decided to form the intrinsic nature of things, or the creation of a prototype, the origin and cause of an item is based. Thus, the meaning of the concept of having a richness and diversity, including several levels ontology, epistemology, teleological and Embryology and the like. From the ontological perspective, the idea is out and before the individual can feel things in objective reality, has the characteristics of the body; from the perspective of epistemological analysis, ideas about the kinds of general concepts, total phase, the scope and other significant allegations; from teleological point of view, the concept of motivation is the goal of all things in the world and on which generated; from embryology speaking, the idea is the very essence of individual things is its concept as a model or copy, or imitate derived out. Based on Plato's idea of thinking, behavior and the Platonic philosophy in mind is different understanding of the phenomenon in the world of opinion, understanding the concept of the world is called knowledge. In his view, the concept of the real world non-material entity independent existence of eternal roots exist in the other world, the various entities in this material world is but a shadow shore side of the world the concept of it.

Since then, the idea of Western philosophy involved discussion framework are based on Plato's philosophy is based. Based on Plato's discourse, the concept can make the following summarized: philosophy is people recognize results of the activities are things behind the appearance essence of 
abstract understanding, is inherent unity complicated objective world understanding, reveal people's understanding of things produced qualitative leap - from perceptual to rational form shape. An authority on the book "Modern Chinese Dictionary", "Ci Hai" interpretation of the concept of Plato have in common. "Modern Chinese Dictionary" interpreted the concept of faith, thoughts, ideas and so on. "Ci Hai" is interpreted as the result of thinking activities, Italian style Similarly, the concept can be understood as perception, thinking, can also be understood as a concept, sometimes referred to as the appearance of objective things in the brain or left general image. In summary, the concept can be explained as follows: the concept is the result of people thinking activity, is a human rational knowledge about the nature of things, it is the principle of unity on things, beliefs and values.

\section{Rule of Law and Human Idea Established Universal Obedience}

To demonstrate this concept of law idea with people isomorphism, we must first clarify the connotation of the rule of law. Although the rule of law in the West thought two thousand years of history, but its basic meaning has not been much change. Two thousand years ago the ancient Greek sage Aristotle, thought the rule of law for the first time elaborated. In its "political science" classics, Aristotle pointed out: "We should note that although the nations of good law, if not all the people to follow, the rule of law is still not the rule of law should contain two meanings: the law was already established universal obedience, and everyone should obey the laws and the formulation itself was good law. "in this state," citizens should abide by a state set out rules for living, so that everyone's behavior has constraints, legal should not be seen (and relative freedom) slavery, the law rather salvation. "thereafter. Aristotle "Liang Fa Jiapu over law-abiding" by the rule of law model of each era thinkers widely accepted and greatly respected, much of the work done after the jurist is at its "good Fajia Pu over law-abiding," the rule of law model expanded. As far as Cicero Roman times, to the Middle Ages - Thomas Aquinas, near to the front of the Renaissance bourgeois Enlightenment thinker Hobbes, Rousseau, Locke, Montesquieu hung, are no exceptions.

Their main task is to Aristotle's "good Fajia Pu over law-abiding," the rule of law to explain its mode of administration to comply with the spirit of the times, the only difference is the difference living in the era background and personal cognitive interests. Jurists to explain Aristotle's "good Fajia Pu over law-abiding," the rule of law model generally involves two aspects. First, according to which the historical stage of social, political, economic, cultural background and the practical requirements, discusses the necessity of universal law-abiding members of society, rationality and legitimacy, and on this basis, with well-designed match practical political and legal system. Such as the separation of powers of the judicial system, fair and efficient trial procedures, protection of human rights lawyer system to ensure that the national political, social, public transparency, order and stability, protection of the rights; the second is under the same background, based on their recognition knowledge and understanding, demonstrate "good law" in the creation of the program and "good law" criterion, a series of criteria, including here in the form of standards and substantive standards.

Despite the differences in academic traditions and ideological thrust and other aspects of contemporary Western methods exist natural law on academic objective analysis positivist law, social law, criticism of law, history, law and many other schools, but the rule of law exposition and argumentation still exhibit a striking similarity. Thus, the "good Fajia Pu over law-abiding," the rule of law model enduring vitality and deep lasting appeal. Contemporary Western jurists generally considered "good law" should be in line with a series of internal and external standards; on law-abiding, they stressed the importance of a series of major principles of judicial activity, procedures and systems, which uses the external system of force to ensure "good law" was an integral member of society to follow. We can say that the history of Western legal theory of the rule of law is the same strain, Aristotle "good Fajia Pu over law-abiding," the rule of law model enriched and improved. So, even though jurists from different levels and angles of the rule of law Analyses, throughout the history of law, rule of law embodied in the law of spiritual civilization, and ideas, principles, concepts and other words used in conjunction. "The spirit of the rule of law, expressed as a set of principles on legal rights and power issues, ideas, value system, which reflects the value of 
human law needs to become the guiding ideology of the system have been designed and law enforcement."

\section{Student Management Innovation Power Balance}

Human rights and social companions, with the introduction of human society, also will be generating power. Power refers to the social body according to certain resources, and in particular the Field, through coercion, domination, influence, authority, persuasion, and so on purpose to induce influence object implementation, in order to achieve the results achieve benefits. That is, power is a force, this force, authorities can influence the object so that the object to achieve compliance with the will power to achieve the interests of the body or authority body.

Organization as a unique phenomenon in human society, the study of human society it is quite concerned about. ? What is it organization "organization is a kind of container, but also the contents of the container; only the structure, but also a process;. Both constraints on human power, but it is also the result of human behavior." So, "When people in order to coordinate a Group activities in order to achieve the objectives and determine a clear program, have given rise to the organization. "in human society, the organization of human activity coordination, forms of cooperation, its essence is to overcome the limitations of individual human beings mental and physical fitness to achieve common target group. With the development of human society is organized and gradually differentiate and grow, the organization of the extent and the level of operating efficiency is an important symbol of social progress and development.

In human society, and the interdependence between organizational power, it was a two-way interaction. From an operational point of view of an organization, the organization can easily be divided into two parts: one is the organizational structure, the other part is the organizational process. Organizational structure is based on the division of the target scale, environmental, technical and other personnel to determine the organization, position, responsibilities, tasks, the performance of a static organization exists; the organization is a process of running the organization, also known as the organization and operation is dynamic organization exists. "Whether it is static or dynamic structure of organization and operation, and power are inextricably linked."

"Power is the prerequisite for the organization People to achieve a common objective, we must rely on the use of power relations, in turn, only direct decision-making process in the pursuit of their common purpose of these negotiations, the ability of one of them other exercise of power. "in essence, the individual who does not require power, it can not generate power only when power from the natural state of human society into the state may have generated and necessary. Social organization is the stage performances of power, the power loss of the organization, and the impact would be on the implementation of virtual home power, by virtue of the power will be nothing. At the same time, the organizational structure also determines the power structure within the organization. Within formal organizations, in order to guarantee the effective operation of the organization, the distribution of power between the individual members has strict rules. Informal internal organization, between individual members Although there is no clear distribution of power, even if the interaction between members will form a relatively stable relationships, such relationships is the power relations.

The role of power by organizing the process of emerging. Organization members are not simple and the corresponding concentration of resources or a combination of automatic, it is the community members for collective action in order to achieve the same goal and collaborative efforts. In other words, social organization is not only static, but also dynamic. To some extent, the completion of the organization's mission, goals of the organization, but the organization dynamic development of a temporary state. Organizational process includes two elements: First, the different combinations of players become an organism; the second is to make the efficient functioning of the organism to achieve the objectives and functions of the organization. Typically, the organizational elements are combined into an organic whole and allowed to achieve organizational goals-led force called organizational power. However, the organization of the powers of action has two sides. Sociology of organizations believe that there is a wide variety of power relations in an internal organization, who 
can promote their endogenous function enables optimal release state, called the forward power. On the other hand, it is a negative force. Forward power is concentrated endogenous functional concerns the organization, go all out to promote the release of functional organization of guided tissue surrounding the target tissue, the power to mobilize all forces to achieve organizational goals, the organization dominant factor benign operation. To focus on the negative power of exogenous tissue function and derivative function, the pursuit of something other than the function of endogenous tissue, often leads to a non-benign run organizations.

\section{Conclusion}

Assume responsibility is to protect the free and comprehensive development, but also in the responsibility to play to benefit students in the harmonious development of collective life. Students in most of the one-child, no brothers and sisters living with the family experience, the lack of mutual concern and understanding of peers, in their dealings with people outside the family in order to easily form a self-centered, resulting in difficulty among students get along. Students at puberty, physical and psychological aspects mature, eager to get the respect of others, eager to communicate with peers. In the high school entrance examination pressure, learning to become its main task, this desire can only be suppressed in the mind, it is difficult to be realized. After entering the university, living environment changes, the collective life become the norm, long-term solitary experience, difficult to get along in the collective life. Away from their parents, and lack of communication with the students, prone to a variety of psychological problems. Assume responsibility for education for college students understand the new life given itself a new collective responsibility, only in the collective life that everyone comply with collective agreements, in order to improve relationships in the phenomenon of indifference and create a harmonious and healthy environment for the growth. Therefore, the responsibility to play in education can compensate for Students collective life deficiencies, mining collective life potential, understanding the collective life of responsibility, adjust the collective life behavior, experience of collective life in the fun, freedom and harmonious collective life comprehensive development.

\section{References}

[1] Cheng Yan Lei: "On the Definition of the Judicial Involvement in the Disputes between students of colleges of" contained in the "China Education" 200521.

[2] Lv Lisha: "Restriction of judicial review of administrative power in Universities" contained in the "China Education" 200612.

[3] IN HIGHER Beijing: "The Value of Student Appeal System in Building Harmonious Universities" contained in "Modern Education Science" 20065.

[4] Houshu Dong: "Management of College Students due process" contained in the "Higher Education" 2004, No. 5.

[5] Zhang Wenxian: "justice, democracy, integrity, identity, harmony and build a value basis to talk about harmonious campus" contained in the "China Education" 200521.

[6] Pengyang Red: "From the Legitimacy of Modern University System" wearing in "China Education" 200921.

[7] Juan: "Implementation Status and Problems of Students Hearing System" contained in the "Shanghai Education and Research" 200412. 